\title{
AN EXCURSION INTO PHARMACOLOGY: CURARE IN MEDICINE
}

by

\author{
RANYARD WEST*
}

\section{INTRODUCTION}

IN our present age of specialization, it is not easy to move from one branch of medical study to another in pursuit of a single piece of research, a single enquiry.

Fifty years ago, Sir Thomas Lewis wrote that on occasion it may be desirable for the clinical scientist to become his own pharmacologist. And fifty years ago, the present writer, a clinician, made an excursion into pharmacology in pursuit of an elusive quarry, curare as a therapeutic agent.

At that time, pharmacology was a somewhat different discipline from what it is today: the whole animal was, I think, used more; its organs were stimulated and records taken in situ: the smoked drum was still in evidence. The course and methods of pharmacology that we had followed as students could come back readily to hand ten years later, particularly if, as was our custom in London, the budding clinician paved his way to recognition by "demonstrating" for a time in the physiology or other scientific department of his hospital medical school. Though problems might be clinical, the laboratories were there and welcoming. We did not feel it a foreign excursion to get into them in order to try to solve our problems.

Curare first became a therapeutically effective agent during the 1940s, when A. E. Bennett and his colleagues introduced it as a modifying agent in electropexy, ${ }^{1}$ and Griffith and Johnson first exhibited it as an anaesthetic adjuvant. ${ }^{2}$ A third use in medical practice arose during the 1950s, when Lassen and his colleagues, having established the treatment of acute poliomyelitis, realized that acute tetanus poisoning could be effectively handled by the same means - that is, by tracheostomy and positive pressure respiration, with the administration of $d$-tubocurarine intravenously to allay the tetanic convulsions. ${ }^{3}$

For curare to become established successfully in each of these three fields, certain pre-conditions were required. First, a stable preparation of curare had to be secured, of constant action and constant strength, and free from unfavourable or uncontrollable side-actions. The drug had to be available in adequate quantities; and a satisfactory means of artificial respiration was necessary. With the exception of posi-

* Ranyard West, DPhil, MD, MRCP, Craignethan, Kirkcudbright DG6 4BG, Scotland.

1 A. E. Bennett, 'Preventing traumatic complications in convulsive shock therapy', J. Amer. med. Ass., 1940, 114: 322-324; A. E. Bennett, A. R. Mclntyre, and A. L. Bennett, ibid., p. 1791.

${ }^{2}$ H. R. Griffith and G. E. Johnson, 'The use of curare in general anaesthesia', Anaesthesiology, 1942, 3: $418-420$.

${ }^{3}$ H. O. A. Lassen, M. Bjфrneboe, B. Ibsen, and T. Neukirch, 'Treatment of tetanus', Lancet, 1954, ii: 1040-1044. 


\section{R. West}

tive pressure respiration, these conditions were made possible by work done earlier, particularly during the previous decade, the 1930 s.

As a clinician, my own interest in the "taming" of curare arose in a peculiar way. An unusual case of what was then sometimes known as "neurological tetany" - a characteristic "tetany" spasm and posture without the characteristic chemical serological changes ${ }^{4}$ - had led me to embark upon a somewhat ambitious investigation into the neurological mechanism of tetany, studying this in the tetany produced by parathyroidectomy in dogs. ${ }^{5}$

For this work, Hamilton Hartridge, then professor of physiology at St Bartholomew's Hospital, London, kindly gave me facilities in his laboratory, and also made the following suggestion: "Before you interrupt any nerve pathways surgically, why not try curare? It will paralyse the nerve-endings, and tell you whether the spasms of tetany constitute a purely muscular phenomenon, or not".

\section{THE LISSIVE EFFECT*}

At that time (1929), curare consisted of lumps of a thick, black, toffee-like substance. It reached the museums and laboratories of the civilized world through traders and explorers, who obtained it in hollowed gourds, earthenware pots of varying sizes, or bamboo tubes, from one or other of its remote South American sources.

Hartridge and I performed the suggested experiment together, using a crude curare which we obtained from Burroughs Wellcome \& Co., who had bought it in Paris. We fully expected the result to show one of two things, either (1) a paralysis of the dog by curarization without removal of its tetany, or (2) a paralysis of the dog with removal of its tetany. We were startled to find that the tonic, clonic, and fibrillary muscular contractions characteristic of the tetany were all removed, and the musculature returned to seemingly normal function-all in response to sub-paralytic doses of curare - indeed, with a dosage so low as to leave the animal with apparently full motor power. Serum calcium estimations were made and did not change: the recovery was therefore not due to a chemical removal of the tetany, such as happens if parathormone is administered. 6

This was the basis of our drive for curare, its alkaloids, and their differential pharmacology, in 1930. The clinical possibilities were exciting. For there were no drugs available to relax the spasticities of hemiplegia and paraplegia with which our neurological wards and out-patients were crowded. A clinical trial of crude curare appeared to me to be justified; and, once our findings in dog-tetany were published, we received a number of kind gifts of curare to this end. We obtained further supplies by purchase. The curares were all tested on frogs, small mammals, and dogs. The results set us our next problem.

Of seven specimens of crude curare that came to us, only two showed the selective

\footnotetext{
'R. West, 'Pituitary cyst', ibid., 1931, ii: 69-71.

s R. West, 'Studies in neurological mechanism of parathyroid tetany', Brain, 1935, 58: 1-20.

- H. Hartridge and R. West, 'Parathyroid tetany in dogs, and its abolition by curare', ibid., 1931, 54: 312-319.

* "Lissive" means "selectively removing rigidity".
} 


\section{Curare in medicine}

relaxation of the muscles of a dog in tetany. One of these was the gift of Sir Charles Sherrington at Oxford; it was obtained in a native earthenware pot and thus was presumed to have come from the Orinoco river area of Venezuela. The other was the curare from an unknown source that we had obtained through Burroughs Wellcome. Our communication of this differential finding followed hard upon the heels of the first announcement of the lissive effect with which we had been so pleased. ${ }^{7}$

Hartridge and I now found ourselves faced with the long-standing puzzles of the chemistry and pharmacology of curare. These were problems not to be quickly solved. Meanwhile, I set up a cautious clinical trial, in the first place of the two curares that had given good results in dog tetany. Burroughs Wellcome kindly filtered and sterilized these curares, and put them up in glass ampoules, as a clear brown liquid.

I was fortunately placed for undertaking this research. It was before the inception of the British National Health Service, in the heyday of the dominance of the voluntary hospitals. Upon such research no legal restrictions were placed: there was no Dunlop Committee. I was able to use cases at the Hospital for Nervous Diseases at Maida Vale, where I was then a medical registrar; at the National Hospital for Nervous Diseases at Queen Square, through the courtesy of Dr Arnold Carmichael, recently appointed by the Medical Research Council as director of research there; and from late in 1929, I had, in addition, my own beds at the Seamen's Hospital at Greenwich, into which I was permitted to admit cases (to beds not required for seamen) for research purposes. Commencing with very small doses, and never increasing the dose by more than fifty per cent of the previously ineffective dose, I injected subcutaneously the sterile curare extracts. Dosage was calculated from our dog doses.

In this series of patients, which included five cases of pyramidal spasticity and four cases of extra-pyramidal (Parkinsonian) rigidity, Sherrington's curare was used throughout. The rigidities relaxed selectively in all cases, though the tremor of Parkinson's disease might concomitantly increase. Improvement could usually be maintained with the pyramidal tract spasticities: the Parkinsonian post-encephalitics usually ended by preferring one of the then regularly used drugs, scopolamine, stramonium, or atropine. The periods of relaxed muscle tone facilitated physical treatment where this was helpful. I published my results, ${ }^{8}$ which certainly suggested that something in some curares might have a place in our scanty armamentarium for treating chronic nervous disease.

Further shocks were in store for us, however, as Hartridge and I began to examine the various other curares that came to our laboratory. In 1930, curare was available in considerable quantity - when looked at in terms of frog dosage, as it then was by most physiologists. But for use in large animals, or in man, these quantities were small. The material was also unreliable. We found that the content of a gourd pot, or bamboo might prove to be a powerful curare poison; or it might readily cause strychnine-like convulsions with varying or no paralytic action being present. Or, again, the specimen might prove to be practically, or entirely, inert.

Neither were supplies to be depended upon. It seemed doubtful whether curare was produced anywhere in the world at that time. The results of our early

'Ibid., p. 508.

'R. West, 'Curare in man', Proc. R. Soc. Med., 1932, 25: 1107-1116. 


\section{R. West}

enquiries, and our rough preliminary chemical and pharmacological investigations, showed that we had a long way to travel. We needed expert chemistry. I needed to know more pharmacology. Finally, we needed plant material, to discover what plants should be searched for, and whither an expedition in search of plant ingredients of curare could best be sent, or encouraged to go. At this stage (1931), the problem of the chemistry of curare and the question of expeditionary help were inter-related. Ideally, so it seemed to me, we should try to find a clearly lissive curare (or obtain from a curare a lissive chemical fraction), become aware of the geographical source of that curare, and institute plant collections in that region.

Sir Charles Sherrington's specimen suggested the Orinoco basin geographically: it was where pot curare usually came from. I accordingly reported our success with Sherrington's pot curare to Dr J. W. Trevan of the Wellcome Physiological Research Laboratories. I also told him of the confusing pharmacological actions we were beginning to meet with, and repeated to him a comment made to us by $W$. $E$. Dixon, veteran pharmacologist at Cambridge, to the effect that we should find that curare could "act on sympathetic ganglia, as well as on motor nerve endings". I think it was the first time any of us had heard this: it foreshadowed the "nicotine-like" action I was frequently to encounter in later fractions. Dr Trevan told me that the Wellcome Laboratories had already received further supplies of curare, again, he thought, "from France". He promised me further autoclaved material, and said he "would try to isolate curarine". As regards an expedition, his commercial firm, Burroughs Wellcome, had asked a research expedition of theirs, about to depart for the Amazon, to try "to get the secret of the curare plant" from the natives.

By this time I was also in touch with Sir Walter Fletcher, secretary to the Medical Research Council. I held Sir Thomas Lewis's view that the clinical scientist may usefully make himself "his own pharmacologist". For the chemistry of curare we must have an expert. But I had in mind to learn the necessary pharmacology myself. Sir Walter Fletcher volunteered that Dr H. H. Dale could probably give me space for dogs at the Medical Research Council's laboratory at Hampstead. I did not take this up at once. With a Londoner's desire to escape from London, I preferred to stay on at Barts for the time being, in the hope that a period at Oxford might fit into my programme later on. But shortly afterwards, Sir Walter Fletcher wrote to me that "some of these questions relating to curare ought to be taken up seriously and early; and I should be glad if you would talk this over with Dr Dale".

So, to Hampstead, and my first personal experience of H. H. (later Sir Henry) Dale. He showed immediate grasp of the whole problem. Not only did he approve of my clinical trials of curare, but he suggested that the veteran Henry Head, who was then severely stricken with paralysis agitans, might like to be treated with curare, as a pioneer, in line with his earlier heroic sensory-nerve section on himself. This proposal did not materialize. Whatever Head himself may have thought, the idea was rejected by his own clinical neurologist, properly, at that stage, I thought. Dale also took up the chemical problem. To my delight, he said he would not wait for plants, but get to work on the crude curare, and "could put a chemist onto it right away, if he had a free hand". He did not, however, wish "to interfere with any work already started elsewhere in response to your enthusiasm"! 


\section{Curare in medicine}

Early in November 1931, I received a copy of Trevan's definitive reply to questions asked him by Sir Walter Fletcher on behalf of the Medical Research Council. Burroughs Wellcome would not go ahead chemically until they could obtain "the plant concerned"; and their present expedition, already at Manaus, had reported that a proper search required a larger expedition than they had mounted, and one prepared to "go some distance into the very dangerous and unsettled interior". Trevan had previously confided to me his opinon that "Dale will get out the alkaloids if we don't"; and, further, that "curare may well be where ergot was before Dale took it up". Since Dale had been eminently successful with ergot, this looked like business!

Of the traditional curare regions of South America, British Guiana was undoubtedly the region most easily approached from Britain: we had a competent colonial administration there. From a clinical point of view, the pot curare areas of the Orinoco basin were at once most desirable and most elusive: Sherrington's pot had yielded a lissive curare. So, too, had Burroughs Wellcome's curare from an unknown source. It came to us from Paris: it might well be Amazonian, and therefore of bamboo (tube) origin. Amazonia at first appeared a hopeful possibility for collection of material: and I was fortunate in finding in the British Museum a good, well-labelled specimen ("Ucayali River, 1871"), inside its bamboo tube. I was still more fortunate in being allowed to abstract a portion and take it to my chemical collaborator, Harold King (see below) who was most fortunate in being able to extract from it his first pure dextro-tubo-curarine chloride. ${ }^{9}$ But that was in 1935 , and I have anticipated.

By enquiry from the secretary of the Royal Geographical Society, I learned in the autumn of 1931 of two imminent expeditions to the Amazon basin. Dyott, a wellknown explorer, wrote that he "could, perhaps, collect curare, but not plants". Professor J. W. Gregory of Glasgow, a geologist, was to leave early in the New Year on a canoeing expedition down the Amazon from very high up the Ucayali branch. I saw Gregory, and he promised to keep a bright look-out: "but I shall be travelling very fast". Sadly, he was drowned during the course of his descent. A colleague wrote later that no curare had been met with by the expedition.

With the Orinoco, the region associated with Sherrington's lissive pot curare, no link was obtainable. Nor did King succeed in supplying me with a lissive fraction from our limited supply of pot curare. This created a gap in our knowledge which was never filled.

We settled then, for British Guiana, I communicating directly with key local figures, the Medical Research Council supporting us through the usual, but powerful, governmental channels.

BOTANY AND FIELD WORK

The colony of British Guiana enjoyed an efficient forestry service. Early in 1932, their assistant conservator of forests, T. A. Warren Davis, returned from an expedition into the interior of the colony made from his station on the Mazaruni river. An object of the expedition had been the collection of rare plants.

N. Y. Sandwith, of the Royal Botanic Gardens, Kew, described this expedition as

'H. King, Nature, Lond., 1935, 135: 460. 
"a very important one". ${ }^{10}$ Nine different species of strychnos plants were collected, three of which were traditionally associated with native preparations of curare: (i) Strychnos cogens, a rarely collected specimen, in scant supply, but repeatedly mentioned by the famous botanists, Richard and Robert Schomburgk, and identified by the latter as the effective ingredient of "cumarawa", an alternative poison, the native Indians said, to curare (or "urari") proper; (ii) $S$. toxifera, the effective agent in the curare prepared by the Macusi Indians, and widely distributed in British Guiana and elsewhere; (iii) S. pedunculata, which, as "Yakki", provided a further, and perhaps alternative, ingredient of "Macusi" curare. This strychnos was rediscovered by Davis during this expedition; but, like $S$. cogens, was only obtainable in small quantities, suitable for botanical identification, but insufficient for chemical or pharmacological assay.

Shortly after shipping this consignment of botanical specimens to Kew Gardens, the conservator of forests was, at our instigation, and through the good offices of the Medical Research Council and the colonial governor, requested to send a further expedition into the interior of British Guiana in order to collect $S$. toxifera in quantity sufficient for chemical analysis, and also to make substantial collections of the bark of any other plants likely to be associated with curare. The response from the colony was excellent: and very soon fine quantities of strychnos bark reached my laboratory (by now at Oxford). One consignment of $S$. toxifera weighed eighty pounds. In all cases, duplicate botanical specimens were sent to Kew Gardens for identification.

It transpired, as one might have guessed, that the colonial forestry department, and particularly an officer as keen as Warren Davis proved to be, already knew a great deal about plant material in the region, and its native associations. Davis's knowledge of habitat, and his experience in collecting rare species for and with N. Y. Sandwith in an earlier expedition (1929) ${ }^{11}$ - one in which $S$. diaboli (Sandwith) was obtained for the first time - made him just the explorer-botanist we needed. The only trouble was that, in the three subsequent journeys Davis made on our behalf, he would have liked to go farther than the budgets of his department allowed. To his great regret, he was never able to collect $S$. cogens in quantity sufficient for chemical and pharmacological trial by us. I do not know if it has even now been collected in quantity sufficient for adequate chemical analysis or full pharmacological appraisal.

Meanwhile, as a result of his expedition of 1932, Warren Davis collected, packaged, and shipped to us, four species of strychnos, and one rubiaceous plant, all in quantities that sufficed for the alkaloidal material to be extracted and its reactions tested pharmacologically. ${ }^{12,13}$ Where suitable, the effects of these alkaloids upon spastic disease were also observed. ${ }^{13}$

\footnotetext{
${ }^{10}$ N. Y. Sandwith, Kew Bulletin, 1933, no. 7 and no. 8, p. 395.

11 N. Y. Sandwith, ibid., 1931, p. 486.

12 R. West, 'Pharmacology and the therapeutics of curare and its constituents', Proc. R. Soc. Med., 1935, 28: $565-578$.

${ }^{13} \mathrm{R}$. West, "A pharmacological study of derivatives of two specimens of tubo-curare and an examination of four members of genus strychnos and one rubiaceous plant associated with the curares of British Guiana', Arch. internat. Pharmacodyn. Thérap., 1937, 56: 81-116.
} 


\section{Curare in medicine}

\section{CHEMISTRY AND PHARMACOLOGY}

As prospective chemical collaborator, Dale introduced me to Harold King of his laboratory staff. King was a very experienced alkaloidal chemist whose interest in the purification of curares was easily aroused in the context of Dale's own current work on neuromuscular transmission by acetylcholine, which transmission curare inhibits. King and I worked in close collaboration through the six years 1932-37. His many chemical fractions were all examined pharmacologically by me.

First of all, and while I was still with Hartridge in London, King and a gifted medical student, A. Stephens, fractionated the various crude curares that we had accumulated; ${ }^{12}$ though for their preparation for human clinical trials I still relied on the Wellcome Laboratories. Later, and largely after I had moved to Oxford, King supplied me with samples of all the alkaloidal material that could be extracted from the barks shipped to us from Guiana - a very considerable chemical task. ${ }^{13}$

In January 1934, I moved into Professor J. A. Gunn's pharmacology department at Oxford. Gunn invited me to demonstrate for him, gave me splendid laboratory facilities, and taught me how to recognize (and where possible assay) the various actions of the curare fractions King was producing - all except curare bronchospasm, in which my expert helper was K. J. Franklin, the senior demonstrator, and later professor of physiology at Barts.

I was anxious not to deepen a rut produced by thirty years of London life; and I had quite deliberately approached Oxford on this matter of location. My own hospital beds, and my main access to neurological beds, were in London and must not be given up. But to work directly under the Medical Research Council I should have had to cross central London daily from my home at Blackheath in the south to Hampstead in the north; and this did not appeal. Pharmacology now occupied very much of my time: a quiet, sequestered laboratory, such as Gunn ruled over at Oxford, was just what I needed. I was delighted when the message came, and I could be out of the bustle of London for the major part of the week. It was an arrangement that lasted for four years.

Hartridge was most generous about my move to Oxford. A great mechanist, Hartridge always had many enterprises awaiting his skilful intervention. But he had enjoyed our amateur attack upon curare; and between 1930 and 1932, he designed for me two "automatic rheotomes" for measuring electrical reactions, and a simple but effective apparatus for measuring and recording spasticity. ${ }^{8}$ He surrendered his amateur chemistry to King with perfect grace. He kindly allowed me to continue to use his laboratory at Barts for my work with dogs and parathyroid tetany, which was not completed until $1935 .^{5}$

By the time King's chemical work on the curare plants began to come to hand at Oxford, I had become accustomed to some of the actions to be expected. I kept hoping that a single alkaloid would be obtained pure, and that it would exhibit a lissive effect in spastic diseases in man. It was the removal of human rigidities that I sought; though a separation in favour of the dog-tetany was not without interest, for it might indicate a mixture of central- and peripherally-acting drugs (or actions), and so become adjustable for therapeutic use in man.

In pharmacology, Gunn's help was minimal, but definite and authoritative. He 


\section{R. West}

would push up his spectacles, peer at the twitching frog, and ejaculate: "Nicotine! Try it on the vagus ganglion!". The senior "lab. man", Long, assisted me, and would know how to do the experiment. I was no longer on my own.

It is unnecessary to detail the pharmacology of the consignments that arrived from Guiana, sometimes in my laboratory, sometimes in Harold King's, between 1932 and 1937. Details are to be found in our published papers. ${ }^{12.13} \mathrm{~A}$ brief summary follows.

In this account I have already mentioned that the pharmacology of our various crude curares had proved most variable. In the event I found that an alleged "curare" might be found to contain (1) a curariform action, (2) a nicotine-like action (more prominent with some curares than others, and never found alone), (3) a central nervous excitant (strychnine-like) action, sometimes more prominent than its curariform effect, (4) a central nervous depressant action, seldom prominent, and (5) in curares containing $S$. toxifera - and in general in calabash curare - a bronchoconstrictor action.

King obtained $d$-tubocurarine pure in 1935,9 and I recorded its pharmacology then. ${ }^{12}$ As for the alkaloidal plant extracts, most of them impure, with which King provided me, the actions of the various extracts comprised, between them, the pharmacological effects listed above. ${ }^{13}$ Semi-crystalline (calabash) curarine, and the pure alkaloid, diaboline, deserve special mention, though the reactions of the former are now familiar.

Curarine has a curarizing action stronger than that of pure $d$-tubocurarine. It also has a bronchoconstrictor action which is delayed, even in the isolated tracheal ring of the cat, ${ }^{13}$ and is believed to be due to the liberation of histamine. ${ }^{14}$ The pharmacology of diaboline is described under $S$. diaboli below.

The pharmacology of the more important barks (stem-barks, I think, in all cases), collected by Davis, and chemically extracted by King, may be summarized as follows:

1. S. toxifera. Considerable quantities of bark from Guiana enabled King to supply curarine for assay, for trial in tetanus, and to send to chemists abroad. In treating tetanus, I was forced to use curarine as the only alkaloid then available; $d$ tubocurarine, though isolated, remained in very short supply, its plant source still unknown. The unfortunate tendency of curarine to produce or facilitate bronchospasm led me to issue warnings against its general clinical use. ${ }^{15}$

2. S. erichsonii showed a preponderance of a convulsant - strychnine-like - action. This was accompanied by a curarizing action and a nicotine-like stimulation of respiration and intestinal movements. Extracts were lissive in dog-tetany. But they increased, rather than diminished, the spasticity of one case of paraplegia. Work on the alkaloids of this strychnos was accordingly abandoned..$^{13}$

3. S. diaboli. Extracts were similar in action to those of $S$. erichsonii, with the addition of a depressant action on the central nervous system. Spinal cord excitation was active, though delayed. The extracts were given intramuscularly or intravenously. ${ }^{13}$

From $S$. diaboli, a pure alkaloid diaboline was obtained by King in 1936, and examined by me at the time. It was described by Dr Boris Krukoff of the New York Botanical Garden as being the "first pure alkaloid to be obtained from a South

14 West, op. cit., note 13 above, pp. 88, 114.

${ }^{15} \mathrm{R}$. West, 'Intravenous curarine in the treatment of tetanus', Lancet, 1936, i: 12-16. 


\section{Curare in medicine}

American strychnos". ${ }^{16}$ Both the chemistry and the pharmacology of diaboline are interesting, and perhaps important. Chemically, diaboline is related to strychnine, through the Wieland-Gumlich aldehyde. ${ }^{17,}{ }^{18}$ Pharmacologically, it has, in addition to a weak curare action, a delayed strychnine-like action in mammals. In man, diaboline increased spasticity in a single case of spastic paraplegia, but it was lissive in dog-tetany. ${ }^{13 *}$

4. Guettarda acreana, (native name "Yakki"), though not a strychnos, is an alleged constituent of "Macusi" curare, and was found to have the same series of actions as diaboline. Its alkaloids were all presented in non-quaternary form. The rigidity of a case of spastic paraplegia was increased by a dose of $2 \mathrm{mgm}$ per kilo of a fresh extract of the plant. ${ }^{13}$

These results were full of hints, but offered nothing tangible. They represented our results in 1937, after four years' work and three expeditions into the interior of British Guiana. Naturally, I was disappointed. Were we to give up, or to try again? We had no plan for collecting plant material from the Amazon areas, whence we thought had come one of our lissive curares, and certainly the tubocurarine that King had isolated. Nor had we penetrated the upper Orinoco basin, the probable origin of Sherrington's pot curare, which I had found lissive in man. We had not even combed the Guianese curare areas thoroughly. S. pedunculata and $S$. cogens, towards which Davis had frequently cast his eye, lay farther afield, probably in the region of the Kanaku or Pakaraima mountains, but involving a four to six months' long expedition which might cost $£ 800$ or more. The Medical Research Council were not prepared to meet such expense.

Reviewing my correspondence with Harold King, I see that 1936 was a very busy year, I chivvying, he patient, if occasionally expostulatory! I had plenty of pharmacology to do on King's many fractions, but no new successes in treating human spasticities to report. Looking back, I think I over-estimated the degree to which those in authority on the Medical Research Council staff shared my enthusiasm. I alone was in personal touch with the officers concerned in British Guiana. Sir Walter Fletcher, reinforced by Sir Henry Dale's interest in the chemical side of the work, had merely asked the colonial government to assist us. No financial support had been offered to the colony, which considered itself a poor one; and its government was inclined to jib at the idea of repeated medical research expeditions paid for by itself! This I learnt from the forest officers concerned.

Authority, whether in office or laboratory, could hardly be expected fully to share my point of view. My enthusiasm was clinically based: I had seen and measured the relaxing spastic limb muscles. The fact that King had isolated pure $d$-tubocurarine from a bamboo curare which came from the upper Amazon tended to lessen rather than increase the interest of chemists in plant collection from another area, such as British Guiana. With the exception of $S$. toxifera, which Davis was able to collect in quantity, and which yielded much to King, and also, eventually, to Wieland and his

\footnotetext{
16 B. A. Krukoff, Memoirs of the New York Botanical Gardens, 1965, 12 (2): 37.

${ }^{17}$ A. R. Battersby and H. F. Hodson, Proc. Chem. Soc., April 1959, p. 126.

18 A. R. Battersby, J. Chem. Soc., 1960, 216: 736.

*See below, pp. 404-405.
} 
colleagues in Germany, ${ }^{19}$ there were only my faint hopes to hold attention on the botany of our own colony. S. diaboli and diaboline did not greatly interest British chemists at that time.

King himself always responded to my enthusiasm, though to respond involved boiling up endless frothy plant extracts with low alkaloidal contents, in deference to my hope that they contained just the right ingredient to cure my patients. Davis alone shared my enthusiasm. He thought he knew where $S$. cogens and $S$. pedunculata were to be found; and he regarded several months' hard labour as an exploring botanist as an entirely reasonable price to pay for the hopes that such a prize aroused. Twice he wrote hoping I would come out and join him on the trip. I considered that I ought to stay at home.

The year 1936 brought our first news that others were at work on curare plant collections. Sandwith at Kew heard from his opposite number, A. C. Smith, at the New York Botanical Gardens, that Boris Krukoff had gone afield in search, among other plants, of $S$. diaboli. Krukoff was at that time collecting for Merck Inc. This search was consequent upon the announcement of our crystallization of diaboline, and its described pharmacology. ${ }^{20}$ King did not, however, publish his chemical characterization of diaboline until 1949, ${ }^{21}$ though my pharmacological account has, through Kruk off, ${ }^{16}$ given him his priority. Dr Krukoff goes on to record his opinion that "the intensive search for Strychnos" in the great basin of the Amazon "all started with N.Y. Sandwith's brief paper in which he describes $S$. diaboli, and King and West's work on its bark". ${ }^{16}$ This is the botanist speaking! But a wider view of the historical record would have to ask what aroused the interest of Drs Major and Molitor of Merck Research Laboratories, and induced them to commission $\mathrm{Dr}$ Krukoff "to investigate and obtain authentic materials of plants entering the curare of the Tecuna Indians of Brazil" - this in June 1935.

Harold King's letter to Nature of March $1935^{\circ}$ had announced at once his intended broad chemical survey of curare, our assembly of curare plants from British Guiana, the lissive action of some crude curares - which it is true, had appeared in 1932 - and his own isolation of $d$-tubocurarine from crude bamboo curare (certainly Brazilian in origin). These facts would be likely to interest Merck Inc.

Again, King and I would never have come together to work on S. diaboli without the drive for lissive material and curare chemistry of ourselves severally, and the botanical associations (field and specialized) that had brought Sandwith and Warren Davis together in Guiana, able to forward us appropriate and ample supplies. It was a widely collaborative effort in which King and I clearly traded a chemist's search for purity against a clinician's search for therapy. I continue to hope that our association has left a useful residuum for continuing enquiry.

TETANUS

While a number of chronic nervous diseases would benefit from a selective relaxation of tonic muscular spasm which left voluntary power intact, tetanus was an acute

19 H. Wieland, K. Bahr, and B. Witkop, Ann. Chem., 1949, 547: 173.

${ }^{20}$ B. A. Kruk off, personal communication, 1963.

${ }^{21}$ H. King, J. Chem. Soc., 1949, $205: 955$. 


\section{Curare in medicine}

disease that cried out to be treated by a muscle relaxant, while antitoxin dealt with its toxaemia.

Following the work of Claude Bernard (1856), which clarified its physiology, the use of curare in tetanus and hydrophobia was many times heroically attempted; but all attempts to establish a method of treatment were dogged by the unreliability of action of the preparations available and the difficulties of artificial respiration, if that had to be resorted to. Over the years, reports came from many countries, and included well-known names: Benjamin Brodie (who preceded the main Bernard and Kolliker publications) in 1839, Vulpian (Paris) in 1857, Sayre (New York) in 1858, Spencer Wells (London) in 1859, to mention just a few of the pioneers. Throughout the nineteenth century, abortive efforts to arrest tetanic convulsive spasms with curare were made, again and again, particularly in Germany and France..$^{22}$

During the 1920s and 1930s, acute tetanus was rife in certain areas of Britain, including the fen district of East Anglia. L. B. Cole, physician to Addenbrooke's Hospital, Cambridge, took a special interest in this distressing disease. In an investigation published in $1934,{ }^{23}$ Cole used a gourd (calabash) curare, successfully, in an acute case, with an incubation period of only seven days and a consequently poor prognosis. The treatment was supplementary to full dosage of antitoxin, and a supporting regimen which he had built up over the years. He was able to secure a good curare of high potency, but noted with regret the absence of a standard preparation of known composition. Again, in 1935, Cole published a full review of twenty-one cases of tetanus treated since 1927, in three of which he had used calabash curare. ${ }^{24}$ In 1969 , he again reviewed the position of the treatment of tetanus, after present-day treatment had become established. ${ }^{25}$

One other British physician treated a case of tetanus with curare at that time. In 1934, Dr (now Professor) J. S. Mitchell, when a house-physician in Birmingham, treated a boy of sixteen suffering from acute tetanus with a nine-day incubation period, with one injection of $0.5 \mathrm{mgm}$ of a crude curare, followed by injections of a "curine-free curarine" obtained from a Berlin source. $0.1 \mathrm{mgm}$ of the curarine was administered four hourly, subcutaneously, and the dose increased slowly and experimentally until eight doses of $0.5 \mathrm{mgm}$ were given per diem, $48 \mathrm{mgm}$ in all being given during twenty days (calabash curarine is considerably more potent than $d$ tubocurarine). Antitoxin 70,000 units i.v., and avertin anaesthesia were given on the first day. There was marked decrease in muscular rigidity from the very first; and the patient recovered - a most successful outcome. ${ }^{26}$

Between 1934 and 1937, I was able to see and treat a considerable number of patients suffering from very severe tetanus. In 1936 , I described ten cases, ${ }^{15}$ all of them treated with curare or curarine, three of them with curarine given intravenously. In

\footnotetext{
${ }^{22}$ A. R. McIntyre, Curare: its history, nature, and clinical use, Chicago, University of Chicago Press, 1947; K. Bryn Thomas, Curare - its history and usage, London, Pitman Medical Publishing Co., 1964.

${ }^{23}$ L. Cole, 'Tetanus treated with curare', Lancet, 1934, ii: 475-477.

${ }^{24} \mathrm{~L}$. Cole and E. T. C. Spooner, 'Treatment of tetanus, with observations on fate of injected antitoxin', Quart. J. Med., 1935, 4 (15): 295-319.

${ }^{25}$ L. Cole and H. Youngman, 'Treatment of tetanus', Lancet, 1969, i: 1017-1019.

${ }^{26} \mathrm{~J}$. S. Mitchell, 'A case of tetanus treated with curare', ibid., 1935, i: 262-264.
} 


\section{R. West}

this series, fulminating cases were especially asked for and selected, cases in which "a fatal prognosis can be made with little hope of error". ${ }^{27}$ Thanks to Davis's response in collecting $S$. toxifera bark in bulk, King had been able to give me plenty of curarine Boehm's curarine - stable, constant in dose and action, but never a quite pure substance. Bronchospasm, sufficient to require intubation, occurred from time to time. This was not only a feature of the treatment of tetanus: it occurred even in one case of Parkinsonism. ${ }^{28}$

This tendency of calabash curarine to produce bronchospasm was, however, doubly dangerous in treating tetanus. No doubt it was associated with inadequate oxygenation; but we had no sure means of overcoming it. Drinker respirators and Bragg-Paul pulsators were tried and found unsuitable (the Nuffield iron lung was not yet invented). I found a neat French transfusion pump, made by Henry and Jouvelet, that secured a steady intravenous inflow of curarine: a cam "milked" a thick rubber tube, slowly and irresistibly, into the vein. This, combined with a two-way endotracheal catheter, was as far as'we got in the right direction! Routine tracheostomy did not occur to me: intermittent positive pressure remained in the future (though we had it for animals in the laboratory). Here, above all, I ought to have sought the aid of Hamilton Hartridge, who faced with any mechanical problem "saw likely paths to answers wherever he turned". ${ }^{29}$ Regrettably, I did not do so.

Results were accordingly disappointing: respiratory distress always intervening to baffle us. In the end, I concluded that "the only present place for intravenous curarine in therapeutics is its continued experimental use in cases of tetanus in which, by the accepted standards (Cole, 1935) recovery cannot be expected by other means". ${ }^{\text {is }} \mathrm{A}$ comparison of this report in the Lancet of 1936 with a case recorded in the same journal in $1956^{30}$ shows well the progress effected in the treatment of tetanus during those twenty years. In my hands, the effects of curarine on the physiology of respiration was disastrous to its use in tetanus. ${ }^{31}$ Subsequently, curare bronchospasm was shown by Landmesser to occur also with $d$-tubocurarine, though less readily than with curarine. ${ }^{32,33}$

I had only been able to find so many cases of acute tetanus by advertising for them. This I did by writing to strictly professional medical journals, the Lancet ${ }^{27}$ and the British Medical Journal. ${ }^{34}$ To do so, was, however, considered to be a somewhat unusual procedure, a rather personal advertisement. My circumstances were themselves unusual. Unlike the general pattern then followed by honorary physicians on the staffs of voluntary hospitals, I was dependent, financially, not upon any private consulting practice, but upon a Beit Memorial Research Fellowship. Dale agreed that the matter was important; and no direct objection was ever raised by medical colleagues to this

${ }^{27}$ R. West, letter to Editor, ibid., 1934, ii: 1416.

28 . West, 'The action of curarine in respiration', ibid., 1938, i: 432-433.

29 W. A. H. Rushton, 'Hamilton Hartridge FRS', Biogr. Mem. Fellows R. Soc. Lond., 1977.

${ }^{30}$ A. C. Smith, E. E. Hill, and J. A. Hopson, 'Treatment of severe tetany', Lancet, 1956, ii: 550-552.

${ }^{31}$ R. West, 'Action of curarine on respiratory mechanism', J. Physiol., 1938, 91 : 437-446.

${ }^{32}$ C. M. Landmesser, 'Study of bronchoconstrictor and hypotensive actions of curarizing drugs', Anaesthesiology, 1947, 8: 506-523.

${ }^{33}$ C. M. Landmesser, J. G. Converse, and M. H. Harmel, 'Quantitative evaluation of bronchoconstrictor action of curare in anaesthetized patient', ibid., 1952, 13: 275-280.

${ }^{34}$ R. West, letter to Editor, Br. med.J., 5 March 1935. 


\section{Curare in medicine}

unusual method of collecting cases for research. At the time, I was rather proud of it! I suggested that a central repository of clinical research requirements might be established. Those were the early days of clinical research as such.

Unfortunately for me, I had reckoned without the sensational nature of the subject and its consequent interest to the press. "Arrow poison to cure disease" was one caption that I remember. The hospitals to which I was called - once by Radio S.O.S. collected reporters, requests for interviews, and, at night - even in those days - the flash of lights for press cameras. I protested. ${ }^{35}$ Not only did I suffer this direct nuisance over a considerable period ("Death's door doctor fails again"!), but I also received a letter from Professor T. R. Elliott, the secretary of the Beit Fellowship trustees, to tell me that one trustee had enquired how it was that a single fellow's name was so constantly appearing in the press, since "the Beit Advisory Board are firmly opposed to unusual statements in the lay press". Elliott, in accepting my explanation, wrote: "I hope these journalistic devils will be foiled in any further attempt with your name. The only way is to give them no information at all." Wise words!

\section{LATER WORK AND FUTURE POSSIBILITIES}

We had won something. Curarine, or, better, $d$-tubocurarine, might perhaps be made effective in tetanus. But spastic disease awaited a lissive curare, the chemistry of which was quite obscure. For work on spasticity, I thought our botanical net should have been wider, and we should have been prepared to extend it further still. King had produced $d$-tubocurarine from crude bamboo curare, which was known to have come from Amazonia where we had no exploring agents, though we might possibly have linked up with the Americans, who had; and we also had diaboline, which was of great interest to me then, and which later excited the interest of both Swiss and British workers.

After 1937, it was the response of American chemists and explorers that led to further progress in curare therapy. Soon (1938-43), Chondrodendron tomentosum would be brought back to the United States from Amazonia by Richard Gill ${ }^{36}$ and identified as the source of $d$-tubocurarine by the work of Krukoff and Moldenke, ${ }^{37}$ and Wintersteiner and Dutcher. ${ }^{38}$

In 1937, I abandoned curare research, my mind a turmoil of theoretical considerations about the interplay of central nervous excitant, and neuromuscular blocking actions, but with little hope of any early unravelling of the mysteries involved

The missing strychnos plants from Guiana were all found in the end, though years later. In 1954, Davis's successor, D. B. Fanshawe, ${ }^{39}$ collected $S$. pedunculata in the Kanuku mountains and $S$. cogens in the Pakaraima foothills. Both contained alkaloids with a curare-like action. Fanshawe also re-collected $S$. mitscherlichii, in which King found two alkaloids. From the same species, collected this time in Brazil,

${ }^{35}$ R. West, letter to Editor, Lancet, 25 May 1935.

${ }^{36}$ R. C. Gill, White water and black magic, London, Gollancz, 1941.

${ }^{37}$ B. A. Krukoff and H. N. Moldenke, Brittonia, 1938, 3: 1 .

${ }^{38} \mathrm{O}$. Wintersteiner and J. D. Dutcher, 'Curare alkaloids from Chondrodendron tomentosum', Science, 1943, 97: 467-470.

39 D. B. Fanshawe, Brittonia, 1954, 8: 65. 
Marini-Bettolo and his Italian colleagues ${ }^{40}$ later characterized five, and Karrer, Schmid et al.,41 in Switzerland, six alkaloids. Diaboline was fully and most interestingly defined by Battersby and Hodson, ${ }^{17,18}$ as also by Karrer and Schmid. ${ }^{42}$ No differential pharmacology is anywhere reported. The era of the clinically interested pharmacologist was not, even yet, established. Or, perhaps, supplies still proved insufficient for this sort of pharmacology to be undertaken. However, the chemistry of the curare alkaloids was much advanced; and the advance was fully recorded in 1959.43

As in the past, so in the future, the chemistry and pharmacology and therapeutics of curare can profitably proceed hand in hand. Chemistry may differentiate clearly between pharmacological actions, and pharmacology may detect specific effects that prove to be of value to medicine. In whatever way it comes about, the advent of a drug of a truly therapeutic lissive effect in spastic disease - one that will abolish pathological rigidity of muscle and at the same time permit voluntary contraction to take place - this is a desideratum as great in 1984 as it was in 1932. One may perhaps speculate on how this could come about.

A single plant, in yielding a single alkaloid, can certainly provide a strong and reliable curare action. Chondrodendron tomentosum and Strychnos toxifera have both done so; and as a result we have had $d$-tubocurarine and toxiferine and its derivatives available commercially for many years.

Can a single plant alkaloid be found to provide a lissive action? In 1932, it seemed probable to me that the selective lissive removal of spastic muscular rigidity was the result of a mixture of two actions. This could presumably be brought about by one alkaloid only if that alkaloid acted both peripherally (as a curare) and centrally (in the manner of strychnine). In 1935, diaboline seemed to me to act in this way, its peripheral action being still present, though weak, when its central action, after slow absorption of the drug from blood to cerebrospinal fluid, in due course became effective. But diaboline was not lissive in spasticity, rather the reverse.

Unfortunately, different consignments of diaboline, as it was subsequently prepared, have been found to have somewhat inconstant actions. Though this was not the method used by Harold King in 1936, ${ }^{21}$ diaboline has more recently been prepared from the Wieland-Gumlich aldehyde, which is a much more powerful centrally acting agent than diaboline, as the following experiment shows.

In 1971, by the kindness of Professor W. Feldberg, pharmacologist to the Medical Research Council, the Wieland-Gumlich aldehyde was compared with diaboline on a cat preparation in which the drugs were administered by perfusion through the cerebral ventricles, or alternatively introduced by micro-injection into the grey matter of the cerebral cortex in the hippocampal region. Using this method, the effect of both diaboline and the Wieland-Gumlich aldehyde was to cause increased nervous excitation and reflex response, in the same way as occurs with both strychnine and $d$ -

\footnotetext{
${ }^{40}$ G. B. Marini-Bettòlo et al., Mart. Rend. Istituto Super. Sanita, 1954, 17: 851; and Gazz. Chim. Ital., 1954, 84: 1161 .

${ }^{41}$ H. Schmid, P. Waser, and P. Karrer, Helv. Chim. Acta, 1953, 36: 345.

42 R. Karrer and H. Schmid, Helvetica, 1958, 41: 1405.

${ }^{43}$ D. Bovet, F. Bovet-Nitti, and G. B. Marini-Bettòlo (editors), Curare and curare-like-agents, Amsterdam, Elsevier, 1959.
} 


\section{Curare in medicine}

tubocurarine when they are administered in this way. In these experiments, Professor Feldberg was able to demonstrate that the Wieland-Gumlich aldehyde was twenty times as strong as diaboline. ${ }^{44}$ The possibility of contamination of diaboline by the aldehyde in the course of its preparation must therefore be mentioned here: the former was described as "95 per cent pure" when it was sent to me; and much of all of the five per cent impurity may have been due to the presence of residual aldehyde. ${ }^{45}$ It would be nice to have both the Wieland-Gumlich aldehyde and diaboline examined again, pharmacologically, and more thoroughly than I was ever able to do.

There is, to my mind, encouragement for further experiment to be made with such alkaloids of the toxiferine-strychnine series as are held up at the "blood-brain barrier". This would be one possible approach to the task of exploiting the interplay of drugs acting upon the nervous system, with a view to clarifying the lissive action that was found in some crude curares fifty years ago, but has not yet been traced to an alkaloid, or alkaloids, of any plant or plant mixture.

4 Personal communication.

4s This supposition is confirmed by Hoffmann-La Roche, who have special experience in this field, in a letter from Prof. A. Hürlimann to me dated 20 October 1981. 